\title{
Cell pH in the Rat Proximal Convoluted Tubule Regulation by Luminal and Peritubular pH and Sodium Concentration
}

\author{
Robert J. Alpern and May Chambers \\ Department of Medicine and Cardiovascular Research Institute, University of California, San Francisco, California 94143-0532
}

\begin{abstract}
To examine the relative roles of apical and basolateral membrane transport mechanisms in the regulation of cell pH in the proximal convoluted tubule, cell $\mathrm{pH}$ was measured in the in vivo microperfused rat tubule using fluorescence. Decreasing luminal pH by $0.7 \mathrm{pH}$ units caused cell $\mathrm{pH}$ to decrease by $0.08 \mathrm{pH}$ units, whereas a similar decrease in peritubular $\mathrm{pH}$ caused cell $\mathrm{pH}$ to decrease by $0.32 \mathrm{pH}$ units. Inhibition of basolateral membrane bicarbonate transport with peritubular 4-acetamido-4'-isothiocyanostilbene-2,2'-disulfonate (SITS) enhanced the response to luminal fluid acidification. Removal of luminal sodium caused a small transient acidification which was followed by a late alkalinization. Peritubular SITS increased the magnitude of the transient acidification, and eliminated the late alkalinization. The acidification was partially inhibited by luminal amiloride. The results demonstrate sodium-coupled processes on both the apical $\left(\mathrm{Na} / \mathrm{H}\right.$ antiport) and basolateral $\left(\mathrm{Na} / \mathrm{HCO}_{3}\right.$ symport) membranes. Basolateral membrane transporters are more important determinants of cell $\mathrm{pH}$.
\end{abstract}

\section{Introduction}

Transport of protons across the mammalian proximal convoluted tubule (PCT) ${ }^{1}$ involves transport across the apical and basolateral cell membranes. We have previously demonstrated that changes in luminal or peritubular $\mathrm{pH}$ lead to changes in the rate of transcellular proton secretion (1-3). These changes in luminal or peritubular $\mathrm{pH}$ directly affect the rate of proton transport on the apical or basolateral membrane transporters, respectively, and secondarily affect the rate of transporters on the other membrane through changes in cell $\mathrm{pH}$. The degree to which cell $\mathrm{pH}$ changes in response to changes in either luminal or peritubular $\mathrm{pH}$ has not previously been examined. In addition, the possibility

This study was presented at the 18th Annual Meeting of the American Society of Nephrology and has appeared as an abstract (1986. Kidney Int. 29:362).

Address reprint requests to Dr. Alpern, 1065HSE, Division of Nephrology, University of California, San Francisco, CA 94143-0532.

Received for publication 23 September 1985 and in revised form 28 February 1986.

1. Abbreviations used in this paper: $\mathrm{BCECF},\left(2^{\prime}, 7\right)$-bis(carboxyethyl)$(5,6)$-carboxyfluorescein; BCECF-AM, acetoxymethyl derivative of BCECF; PCT, proximal convoluted tubule; SITS, 4-acetamido-4'-isothiocyanostilbene-2,2'-disulfonate.

J. Clin. Invest.

(c) The American Society for Clinical Investigation, Inc.

0021-9738/86/08/0502/09 \$1.00

Volume 78, August 1986, 502-510 that other components of intracellular composition could contribute to communication between the membranes has not been examined.

The mechanism of basolateral membrane bicarbonate transport in the rat PCT has recently been demonstrated to be electrogenic $\mathrm{Na} /\left(\mathrm{HCO}_{3}\right)_{n>1}$ cotransport $(4,5)$. This transporter is similar to that which Boron and Boulpaep (6) first described in the salamander, and Biagi (7) found in the rabbit proximal tubule. In the rat PCT, this basolateral membrane bicarbonate transporter was found to modify its rate in response to changes in peritubular sodium concentration $(4,5)$, peritubular $\mathrm{pH}(4$, 5 ), or cell potential difference (4). In addition, this transporter was inhibited by 4-acetamido-4'-isothiocyanostilbene-2,2'-disulfonate (SITS), but not by amiloride (4-7). Whether this transporter modifies its rate in response to changes in cell composition (i.e., cell pH or sodium concentration) has not been examined.

$\mathrm{Na} / \mathrm{H}$ exchange is generally considered to be a major mechanism of apical membrane proton transport in the mammalian proximal tubule. Studies utilizing brush border membrane vesicles from rat and rabbit cortex have uniformly found an electroneutral $\mathrm{Na} / \mathrm{H}$ antiporter (8-10). An apical membrane $\mathrm{Na} / \mathrm{H}$ antiporter also has been found in the salamander proximal tubule (11). The confirmation of such a transporter in the intact mammalian proximal tubule, however, has relied on the demonstration that acidification is dependent on the presence of sodium and sodium transport (12-17). The recent demonstration that the basolateral membrane bicarbonate transport mechanism is dependent on the presence of sodium, and is affected by changes in cell potential difference secondary to inhibition of sodium transport (4-7), has complicated the interpretation of these studies.

We have recently developed a technique for the measurement of intracellular $\mathrm{pH}$ in the in vivo microperfused rat proximal convoluted tubule (4). In this technique, cells are loaded with the pH-sensitive dye, $\left(2^{\prime}, 7^{\prime}\right)$-bis (carboxyethyl)- $(5,6)$-carboxyfluorescein (BCECF) (18-20). The ratio of fluorescence intensity at two selected excitation wavelengths is a measure of cell pH. This technique provides the experimental basis for direct examination of transporters on apical and basolateral membranes, separately.

The purposes of the present studies were: $(a)$ to examine the relative roles of the apical and basolateral membranes as determinants of cell $\mathrm{pH} ;(b)$ to confirm the presence or absence of an apical membrane $\mathrm{Na} / \mathrm{H}$ antiporter; and (c) to examine the effect of changes in cell composition on the basolateral membrane transport mechanism. The results demonstrate that the basolateral membrane transport mechanism is a quantitatively more important determinant of cell $\mathrm{pH}$ than are apical membrane transport mechanisms. The presence of an apical membrane $\mathrm{Na} / \mathrm{H}$ antiporter is confirmed. The results also demonstrate that the basolateral membrane transporter modifies its rate in response to changes in cell composition. 


\section{Methods}

Experiments were performed using male Wistar rats (Charles River Breeding Laboratories, Inc., Wilmington, MA) weighing 206-268 g. The rats were prepared for microperfusion as previously described $(1,3)$. Briefly, rats were anesthetized with an intraperitoneal injection of Inactin $(100-120 \mathrm{mg} / \mathrm{kg})$ and placed on a heated table which maintained body temperature at $37^{\circ} \mathrm{C}$. The right femoral artery was catheterized for monitoring blood pressure and obtaining blood samples. The left kidney was exposed using a flank incision, and immobilized in a lucite cup. The ureter was cannulated (PE-50) to ensure the free drainage of urine. Rats were infused intravenously with a bicarbonate Ringer's solution $(\mathrm{NaCl}$ $105 \mathrm{mM}, \mathrm{NaHCO}_{3} 25 \mathrm{mM}, \mathrm{Na}_{2} \mathrm{HPO}_{4} 4 \mathrm{mM}, \mathrm{KCl} 5 \mathrm{mM}, \mathrm{MgSO}_{4}$ $1 \mathrm{mM}, \mathrm{CaCl}_{2} 1.8 \mathrm{mM}$ ) at $3.2 \mathrm{ml} / \mathrm{h}$ during surgery, and then at $1.6 \mathrm{ml} /$ $\mathrm{h}$ throughout the rest of the experiment. Proximal tubular transit time was measured after injection of $0.02 \mathrm{ml}$ of $10 \%$ lissamine green dye intravenously, and only those kidneys in which transit time was less than $11 \mathrm{~s}$ were accepted for study. At the completion of surgery, a blood sample was obtained for determination of $\mathrm{pH}$ and $\mathrm{PCO}_{2}$ (model 165 blood gas analyzer, Corning Glass Works, Medfield, MA). The rats had normal systemic acid-base parameters: $\mathrm{pH}=7.47 \pm 0.02, \quad \mathrm{PCO}_{2}$ $=37.7 \pm 1.6 \mathrm{mmHg}$, and $\left[\mathrm{HCO}_{3}^{-}\right]=26.0 \pm 0.8 \mathrm{mM}$.

Pipettes were placed using a Leitz dissecting microscope (Leitz Wetzlar, Rockleigh, NJ). Peritubular capillaries were perfused as previously described (4) with a 12-14- $\mu \mathrm{m}$ tip pipette designed to allow rapid changes between two perfusion fluids. Two pieces of pulled polyethylene tubing (PE-10) inserted into the pipette carried the two perfusion solutions to the pipette tip. Fluid was pushed out the pipette tip by hydraulic pressure which was switched from one series of PE tubing to the other by Hamilton valves (HV and HVP valves, Hamilton Co., Reno, NV) Simultaneously with switching perfusion pressure from one series of inner tubing to the other, an outlet valve was briefly opened in the back of the peritubular capillary pipette holder which caused rapid flow from the tubing and mixing at the tip.

The lumen of a PCT was then perfused using a technique of rapid retrograde perfusion similar to that described by Fromter and Gessner (21). First, tubules were perfused at $40 \mathrm{nl} / \mathrm{min}$ for 5-7 min using a thermally insulated microperfusion pump (Wolfgang Hampel, Berlin, FRG) with a solution containing the acetoxymethyl derivative of BCECF (BCECF-AM, see below), as previously described (4). This length of time was found to be sufficient to load the cells in the perfused loop with BCECF. The luminal perfusion fluid also contained FD and $C$ green dye which allowed delineation of more distal loops of the same nephron. This pipette will subsequently be referred to as the loading pipette.

After 5-7 min, the loading pipette was removed and a second luminal pipette was placed in a more distal loop of the same nephron. This pipette was similar to that used in the peritubular capillary (see above) except that it had a smaller tip (7-9 $\mu \mathrm{m})$.

In previous studies we have demonstrated that perfusion of the peritubular capillaries as described above does not alter the composition of the luminal fluid (4). In order to demonstrate that the luminal fluid composition was similar to that perfused retrograde, control studies were performed where $\left[{ }^{3} \mathrm{H}\right]$ inulin was placed in the luminal perfusion fluid, and fluid was collected from the lumen at a more proximal site. The ratio of ${ }^{3} \mathrm{H}$ counts in the collected fluid to that in the perfused fluid was $1.05 \pm 0.06(n=4)$. Thus, this technique does allow control of luminal and peritubular fluid composition.

The perfusion solutions are listed in Table I. SITS was obtained from International Chemical and Nuclear (Cleveland, $\mathrm{OH}$ ). The luminal loading perfusion pipettes were filled with the control luminal solution (luminal perfusate used in the control period) containing $0.025 \%$ FD $+\mathrm{C}$ green dye no. 3 and $60 \mu \mathrm{g} / \mathrm{ml}\left(7.5 \times 10^{-5} \mathrm{M}\right)$ of the acetoxymethyl derivative of BCECF (BCECF-AM) (Research Development Corporation, Toronto, Canada). This compound does not fluoresce and is lipid soluble. It rapidly diffuses into cells where cytoplasmic esterases cleave off the acetoxymethyl groups forming the fluorescent BCECF, which has four negative charges and thus leaves the cell slowly. Cells were usually loaded until sufficient visible fluorescence was achieved. In previous studies, the half-time for loss of BCECF from the cell was found to be 10-12 min which was greater than that of other fluorescein derivatives tested at $37^{\circ} \mathrm{C}$ in the rat PCT (4).

We have previously demonstrated that tubules perfused with BCECFAM have normal rates of volume and bicarbonate transport (4). Thus the dye itself is not cytotoxic. The dye, however, can cause photodynamic damage to the cell. Indeed, if prolonged light exposure occurs, cells swell and cell $\mathrm{pH}$ decreases. When this was noted, data was rejected. To avoid this problem, minimal light exposure was utilized.

Cell pH measurement. After placement of the pipettes, the dissecting microscope was moved out of position, and a Leitz epifluorescence microscope (MPV Compact system, Leitz Wetzlar) was moved into position. Cell $\mathrm{pH}$ was then measured as previously described (4). In general, fluorescence intensity was greatest in the cells of the loop the loading pipette was in (distal to the location of the loading pipette) and less in subsequent loops. Lumens, capillaries, and surrounding structures did not fluoresce above background fluorescence. Fluorescence was measured in the loop which had contained the loading pipette, and never through the glass pipettes. This was done by use of an adjustable measuring diaphragm. Measurements were made using a $\times 10$ objective. Although the size of the measured area varied, it was usually $\sim 60-80 \mu \mathrm{m}$ square. While such an area includes many cells, there is presently no evidence for cellular heterogeneity in the rat PCT. The measured loop was always well within the capillary perfusion area. Background fluorescence was measured in a tubule which did not contain the dye, but was within the area of capillary perfusion. Background varied only slightly from tubule to tubule. The signal to background ratio varied from approximately 15 to 100 at 500$\mathrm{nm}$ excitation, and 5 to 30 at $450-\mathrm{nm}$ excitation (see below). While intensity of fluorescence was read from a digital display, the pattern of change was followed on a chart recorder (model 689M, Hewlett-Packard Co., Palo Alto, CA).

Analysis. BCECF has peak excitation at $504 \mathrm{~nm}$ which is $\mathrm{pH}$-sensitive, and an isosbestic point where fluorescence excitation is independent of $\mathrm{pH}$ at $436 \mathrm{~nm}$ (4). Peak emission is at $526 \mathrm{~nm}$. As described previously (4), epifluorescence was measured in these studies alternately at 500and 450-nm excitation and with 530-nm emission (interference filters, Corion Corp., Holliston, MA). Fluorescence was always measured with $500-\mathrm{nm}$ excitation followed by $450-\mathrm{nm}$ excitation, followed again by 500 -nm excitation. All results were corrected by subtracting background. The fluorescence excitation ratio $\left(F_{500} / F_{450}\right)$ was calculated as the mean of the two $500-\mathrm{nm}$ excitation measurements divided by the $450-\mathrm{nm}$ excitation measurement. Use of the fluorescence excitation ratio provides a measurement which is unaffected by changes in dye concentration. In order to convert fluorescent excitation ratios to an apparent cell $\mathrm{pH}$ value, results of our previously reported intracellular calibration were used (4).

In some studies, an initial rate of $\mathrm{pH}$ change was calculated, as described previously (4). During a fluid change, fluorescence was followed with 500-nm excitation on a chart recorder. The slope of a line drawn tangent to the initial deflection $\left[d\left(F_{500}\right) / \mathrm{d} t\right]$ defined the initial rate of change of $500 \mathrm{~nm}$ fluorescence. We have previously demonstrated that fluorescence with $450-\mathrm{nm}$ excitation is not measurably affected by cell $\mathrm{pH}$, and can thus be considered constant (4). The rate of change in the fluorescence excitation ratio $\left[d\left(F_{500} / F_{450}\right) / \mathrm{d} t\right]$ can then be calculated using the formula:

$$
d\left(F_{500} / F_{450}\right) / \mathrm{d} t=\left[d\left(F_{500}\right) / \mathrm{d} t\right] / F_{450},
$$

where $F_{450}$ represents the calculated 450 -nm excitation fluorescence corrected for background at the time of the fluid change (interpolated from the measurements before and after the fluid change).

In all studies, the described experimental protocol was performed once in each tubule. In no series were all the tubules from the same animal. Comparisons within the same tubule were made using the paired $t$ test. Group comparisons not within the same tubule were made using the unpaired $t$ test. Results are reported as mean \pm standard error. 


\begin{tabular}{|c|c|c|c|c|c|c|c|}
\hline & $25 \mathrm{HCO}_{3}$ & $5 \mathrm{HCO}_{3}$ & $0 \mathrm{Na}-25 \mathrm{HCO}_{3}$ & $25 \mathrm{HCO}_{3}-0 \mathrm{ORG}$ & $\begin{array}{l}\text { 0Na-25HCO }{ }_{3-} \\
\text { OORG }\end{array}$ & $\begin{array}{l}75 \mathrm{Na}-25 \mathrm{HCO}_{3}- \\
0 \mathrm{ORGSO}{ }_{4} \mathrm{PO}_{4}\end{array}$ & $\begin{array}{l}{\mathrm{ONa}-25 \mathrm{HCO}_{3}-} \\
\mathrm{OORGSO}_{4} \mathrm{PO}_{4}\end{array}$ \\
\hline $\mathrm{Na}^{+}$ & 147 & 147 & & 152 & & 75 & 0 \\
\hline $\mathbf{K}^{+}$ & 5 & 5 & 5 & 5 & 5 & 5 & 5 \\
\hline $\mathrm{Ca}^{++}$ & 1.8 & 1.8 & 1.8 & 1.8 & 1.8 & 1.8 & 1.8 \\
\hline $\mathrm{Mg}^{++}$ & 1 & 1 & 1 & 1 & 1 & 1 & 1 \\
\hline Choline $^{+}$ & & & 147 & & 152 & 77 & 152 \\
\hline $\mathrm{Cl}^{-}$ & 128.6 & 148.6 & 128.6 & 133.6 & 133.6 & 137.6 & 137.6 \\
\hline $\mathrm{HCO}_{3}^{-}$ & 25 & 5 & 25 & 25 & 25 & 25 & 25 \\
\hline $\mathrm{HPO}_{4}^{=}$ & 1 & 1 & 1 & 1 & 1 & & \\
\hline $\mathrm{SO}_{4}^{=}$ & 1 & 1 & 1 & 1 & 1 & & \\
\hline Glucose & 5 & 5 & 5 & & & & \\
\hline Alanine & 5 & 5 & 5 & & & & \\
\hline Urea & 5 & 5 & 5 & 5 & 5 & 5 & 5 \\
\hline Bubbled with $\% \mathrm{O}_{2} / \% \mathrm{CO}_{2}$ & $93 / 7$ & $93 / 7$ & $93 / 7$ & $93 / 7$ & $93 / 7$ & $93 / 7$ & $93 / 7$ \\
\hline
\end{tabular}

\section{Results}

Effect of luminal and peritubular $\mathrm{pH}$ on cell $\mathrm{pH}$. The first set of studies were designed to compare the effects of changing luminal and peritubular $\mathrm{pH}$ on cell $\mathrm{pH}$. Lumen and capillary were first perfused with solutions containing $25 \mathrm{meq} /$ liter bicarbonate $(\mathrm{pH}$ 7.32; perfusate $25 \mathrm{HCO}_{3}$, Table I). Then luminal or peritubular bicarbonate concentration was decreased to $5 \mathrm{meq} / \mathrm{liter}$ ( $\mathrm{pH} 6.63$; perfusate $5 \mathrm{HCO}_{3}$, Table I). Fig. 1 shows the original tracing from a typical experiment. The intensity of fluorescence is indicated by the height of the bars. Measurements with 450-nm excitation are indicated by triangles over the bars, while all other bars are with $500-\mathrm{nm}$ excitation. When luminal bicarbonate concentration is changed between 25 and $5 \mathrm{meq} / \mathrm{liter}$, there are no obvious transients in the recording, and the change in the ratio of fluorescence at 500 - and $450-\mathrm{nm}$ excitation is small. A similar change in peritubular bicarbonate concentration causes a marked transient in the fluorescence recorded with $500-\mathrm{nm}$ excitation, and a large change in the ratio of 500:450-nm fluorescence.

Fig. 2 shows the results in six tubules. Cell pH was $7.31 \pm 0.02$ when lumen and peritubular bicarbonate concentration were 25 meq/liter. When luminal bicarbonate concentration was decreased to $5 \mathrm{meq} / \mathrm{liter}$, cell $\mathrm{pH}$ decreased to $7.25 \pm 0.03(P$ $<0.025)$. Then when luminal bicarbonate concentration was returned to $25 \mathrm{meq} / \mathrm{liter}$, cell $\mathrm{pH}$ returned to $7.34 \pm 0.02(P$ $<0.005$ ). A similar change of peritubular rather than luminal bicarbonate concentration produced a much larger change in cell $\mathrm{pH}$. Cell $\mathrm{pH}$ decreased from $7.34 \pm 0.02$ to $7.04 \pm 0.01$ when the peritubular fluid was acidified $(P<0.001)$, and returned to $7.38 \pm 0.03$ when peritubular $\mathrm{pH}$ was returned $(P<0.001)$. The change in cell $\mathrm{pH}$ when peritubular $\mathrm{pH}$ was decreased by 0.7 $\mathrm{pH}$ units $(0.32 \pm 0.02 \mathrm{pH}$ units) was greater than that observed when luminal $\mathrm{pH}$ was decreased $(0.08 \pm 0.02 \mathrm{pH}$ units; $P$ $<0.001$ ). The observed effect of peritubular $\mathrm{pH}$ on cell $\mathrm{pH}$ agrees with that previously observed by us (4).

The above results demonstrate that the rate of the basolateral membrane transporter is more sensitive to changes in ambient $\mathrm{pH}$ than is the rate of the apical membrane mechanism. It is then possible that changes in the rate of the basolateral membrane transporter, in response to changes in intracellular composition, could blunt the effect of a change in luminal $\mathrm{pH}$ on cell $\mathrm{pH}$. Thus, inhibition of the basolateral membrane transport mechanism could amplify changes in cell $\mathrm{pH}$ in response to altered luminal $\mathrm{pH}$. We and others $(4-7,22,23)$ have previously demonstrated that peritubular SITS inhibits the basolateral membrane bicarbonate transport mechanism.

We therefore next examined the effect of luminal $\mathrm{pH}$ on cell $\mathrm{pH}$ in the presence and absence of peritubular SITS. In order to decrease the amount of intracellular alkalinization in response to SITS (4), peritubular capillaries were perfused throughout with $5 \mathrm{meq} / \mathrm{liter}$ bicarbonate (perfusate $5 \mathrm{HCO}_{3}$ ). Fig. 3 shows the results in 6 tubules. In the absence of SITS, reducing luminal bicarbonate concentration from 25 to $5 \mathrm{meq} / \mathrm{liter}$ caused cell $\mathrm{pH}$ to decrease from $7.13 \pm 0.03$ to $7.05 \pm 0.04$ ( $P<0.001$; Fig.

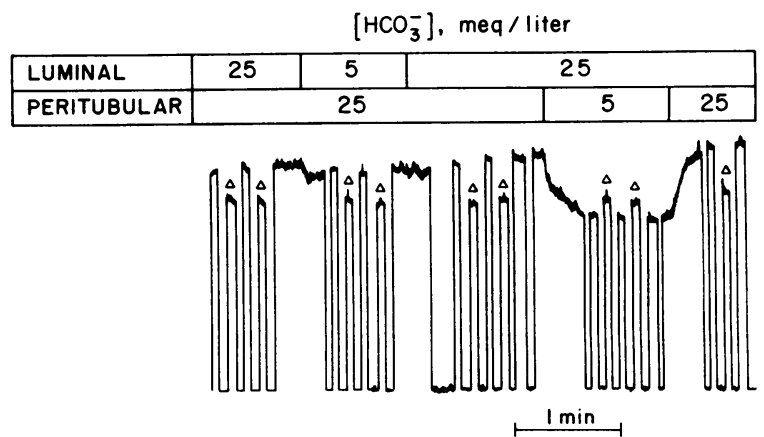

Figure 1. Effect of luminal and peritubular bicarbonate concentration on cell $\mathrm{pH}$, typical study. Lumens and capillaries were perfused with $\mathrm{CO}_{2}$-containing solutions with either $25(\mathrm{pH} 7.32)$ or $5(\mathrm{pH} 6.63)$ $\mathrm{meq} / \mathrm{liter}$ bicarbonate. Intensity of fluorescence in arbitrary units is indicated by the height of the bars. Measurements with 450 -nm excitation are indicated by triangles $(\Delta)$ over the bars. All other measurements are with 500 -nm excitation. When luminal bicarbonate concentration is changed there are no obvious transients in the recording, and the change in the ratio of fluorescence at 500- and 450-nm excitation is small. A similar change in peritubular capillary bicarbonate concentration caused a large transient in the 500-nm excitation tracing and a large change in the ratio between 500- and 450-nm fluorescence. 
3). When luminal bicarbonate concentration was returned to 25 meq/liter, cell pH returned to $7.17 \pm 0.04(P<0.001)$. Peritubular capillaries were then perfused with $0.5 \mathrm{mM}$ SITS for $\sim 1 \mathrm{~min}$, which caused cell $\mathrm{pH}$ to increase to $7.39 \pm 0.07(P<0.005)$. After luminal acidification in the presence of peritubular SITS, cell $\mathrm{pH}$ decreased to $7.21 \pm 0.07(P<0.001)$, and then returned to $7.40 \pm 0.06$ when the luminal fluid was returned to the control pH $(P<0.001)$. Thus, the change in cell $\mathrm{pH}$ in response to altered luminal $\mathrm{pH}$, was greater in the presence of peritubular SITS $(0.19 \pm 0.02 \mathrm{pH}$ units) than in its absence $(0.10 \pm 0.01 \mathrm{pH}$ units; $P<0.025$ ).

It may be difficult to compare cell $\mathrm{pH}$ changes when the initial cell $\mathrm{pH}$ is different as in the previous studies. However, if one compares the response of cell $\mathrm{pH}$ to luminal acidification with peritubular $\left[\mathrm{HCO}_{3}\right]=25 \mathrm{meq} / \mathrm{liter}$ (Fig. 2, periods 1-3), and with peritubular $\left[\mathrm{HCO}_{3}\right]=5 \mathrm{meq} / \mathrm{liter}$ (Fig. 3, periods $1-$ 3 ), it can be seen that the changes in cell $\mathrm{pH}$ are similar in spite of markedly different cell pHs. In addition, if the effect of luminal acidification in the presence of peritubular SITS and a low peritubular $\left[\mathrm{HCO}_{3}\right]$ (Fig. 3, periods 4-6) is compared with that in the absence of peritubular SITS and with peritubular $\left[\mathrm{HCO}_{3}\right]$ $=25 \mathrm{meq} /$ liter (Fig. 2, periods 1-3), the initial cell $\mathrm{pHs}$ are similar, but the change in cell $\mathrm{pH}$ is greater in the presence of SITS $(0.19 \pm 0.02$ vs. $0.08 \pm 0.02 ; P<0.005)$.

Effect of luminal sodium substitution. The next set of studies was designed to examine the effect of luminal sodium substitution on cell $\mathrm{pH}$. Luminal sodium concentration was decreased from $147 \mathrm{meq} /$ liter (perfusate $25 \mathrm{HCO}_{3}$, Table I) in the initial control and recovery periods to $0 \mathrm{meq} / \mathrm{liter}$ (perfusate $0 \mathrm{Na}$ $25 \mathrm{HCO}_{3}$, Table I) in the experimental period. Peritubular capillaries were perfused with perfusate $25 \mathrm{HCO}_{3}$ throughout.

Fig. 4 shows the results of a typical study. Fig. $4 \mathrm{~A}$ shows the fluorescence tracing, whereas Fig. $4 B$ shows a plot of the calculated fluorescent ratios and cell pHs. Once again, in Fig. $4 \mathrm{~A}$, the triangles denote measurements with $450-\mathrm{nm}$ excitation

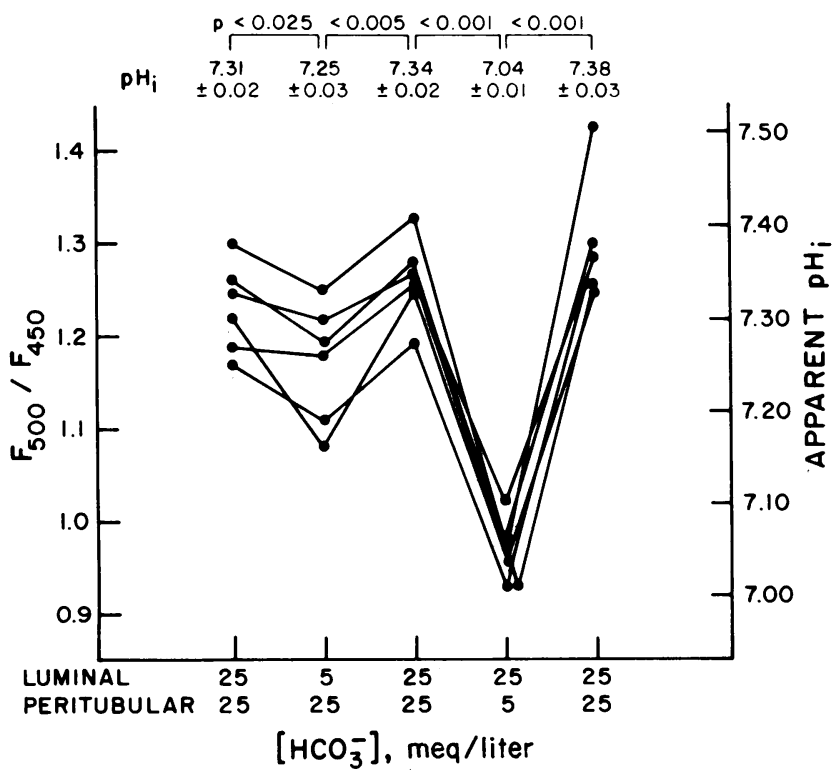

Figure 2. Effect of luminal and peritubular bicarbonate concentration on cell $\mathrm{pH}$. Lumens and capillaries were perfused with $\mathrm{CO}_{2}$-containing solutions with either 25 (pH 7.32) or 5 (pH 6.63) meq/liter bicarbonate, as in Fig. 1. Ordinate shows steady-state fluorescence excitation ratio on left and calculated cell $\mathrm{pH}$ on right.

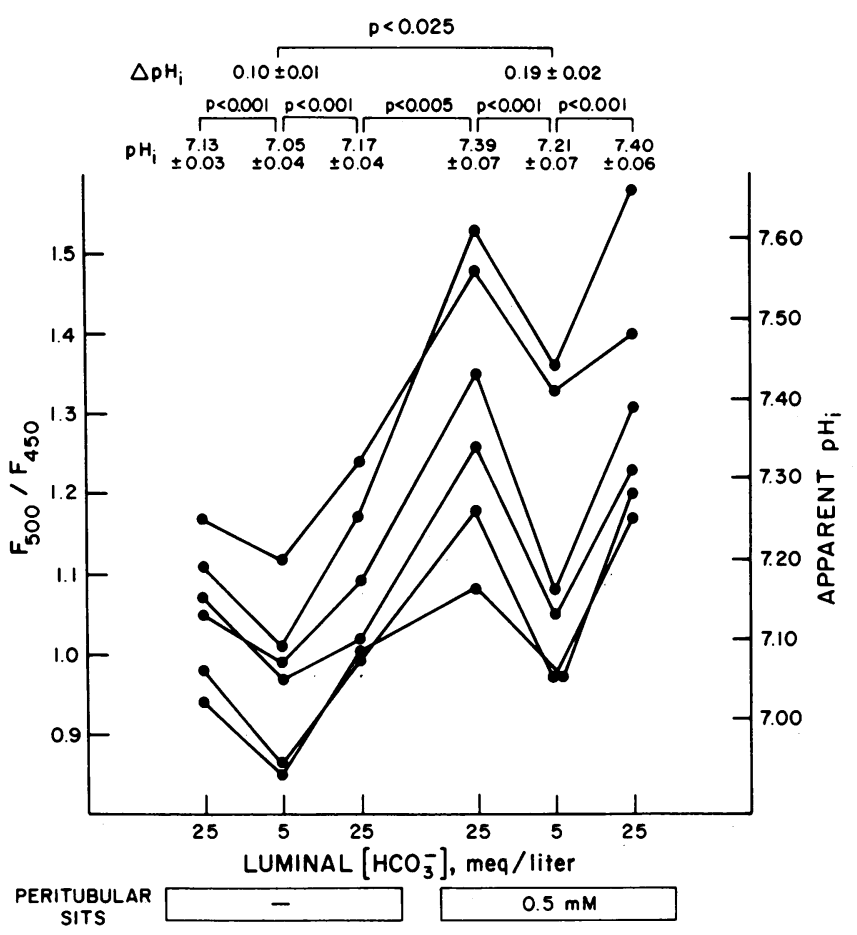

Figure 3. Effect of inhibition of the basolateral membrane bicarbonate transport mechanism on the response of cell $\mathrm{pH}$ to luminal acidifcation. Luminal bicarbonate concentration was changed from 25 to 5 and then back to $25 \mathrm{meq} / \mathrm{liter}$, first in the absence, and then in the presence of $0.5 \mathrm{mM}$ peritubular SITS. Peritubular capillaries were perfused with a solution containing $5 \mathrm{meq} /$ liter bicarbonate throughout. Ordinate shows fluorescence excitation ratio on left and calculated cell $\mathrm{pH}$ on right.

and measurements with 500-nm excitation are unmarked. Removal of luminal sodium caused a transient cell acidification which can be seen in Fig. $4 A$ as a rapid decrease in 500-nm fluorescence and a decrease in the ratio of 500:450-nm fluorescence. This was followed by a delayed cell alkalinization (increase in ratio of 500:450-nm fluorescence) while sodium remained absent in the lumen. Return of luminal sodium then caused an immediate alkalinization (rapid increase in $500 \mathrm{~nm}$ fluorescence) followed by a delayed cell acidification.

Fig. 5 shows the results of similar studies in six tubules. Cell $\mathrm{pH}$ in the initial control period was $7.22 \pm 0.03$. When sodium was suddenly removed from the luminal fluid, cell $\mathrm{pH}$ decreased transiently to $7.06 \pm 0.04$ ( $P<0.005$ vs. control period), and then alkalinized at an initial rate of $0.18 \pm 0.06 \mathrm{pH}$ units $/ \mathrm{min}$ to $7.35 \pm 0.07$ ( $P<0.005$ vs. early reading of experimental period). The final cell $\mathrm{pH}$ was more alkaline than the cell $\mathrm{pH}$ of the control period $(P<0.05)$. When sodium was added back in the recovery period, a similar pattern was observed. Cell pH first transiently alkalinized to $7.45 \pm 0.07(P<0.01$ vs. late readings of experimental period), and then acidified. This cell acidification in the late recovery period, however, did not achieve statistical significance $(P<0.1){ }^{2}$

In these studies three factors might contribute to the transient cellular acidification. First, luminal sodium removal would be

2. In these studies, the final cell $\mathrm{pH}$ was higher than the initial cell $\mathrm{pH}$. This was due to a slow $0.02 \mathrm{pH}$ unit/min increase in cell $\mathrm{pH}$ which occurred in most tubules. Possible mechanisms for this are presented in the Discussion. 
A LUMINAL $\left[\mathrm{Na}^{+}\right]$, meq/liter

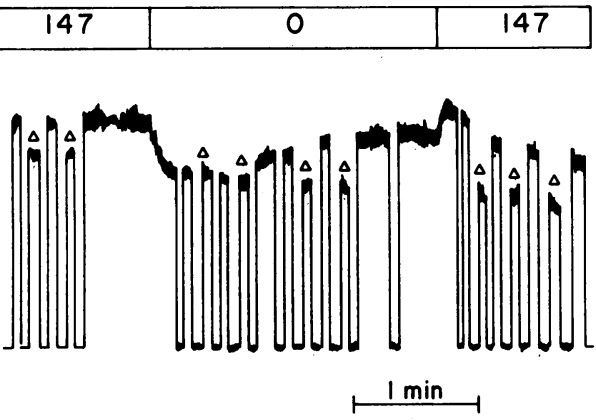

Figure 4. Effect of luminal sodium removal on cell $\mathrm{pH}$ in the presence of luminal organic solutes: typical study. Lumens were perfused with solutions containing $25 \mathrm{meq} / \mathrm{liter}$ of bicarbonate, $5 \mathrm{mM}$ glucose, and 5 $\mathrm{mM}$ alanine, and either $147 \mathrm{meq} / \mathrm{liter}$ of sodium or choline. Capillaries were perfused with a solution containing $25 \mathrm{meq} / \mathrm{liter}$ of bicarbonate throughout. $(A)$ Tracing showing fluorescence measurements. Intensity of fluorescence in arbitrary units is indicated by the height of

expected to drive an apical membrane $\mathrm{Na} / \mathrm{H}$ antiporter in reverse (i.e., proton influx). Second, in the presence of luminal organic solutes (glucose and alanine), luminal sodium removal hyperpolarizes the cell, which would drive bicarbonate out of the cell across the electrogenic, potential-sensitive basolateral membrane transporter (4). Third, decreases in cell sodium concentration and $\mathrm{pH}$ could secondarily drive the basolateral membrane

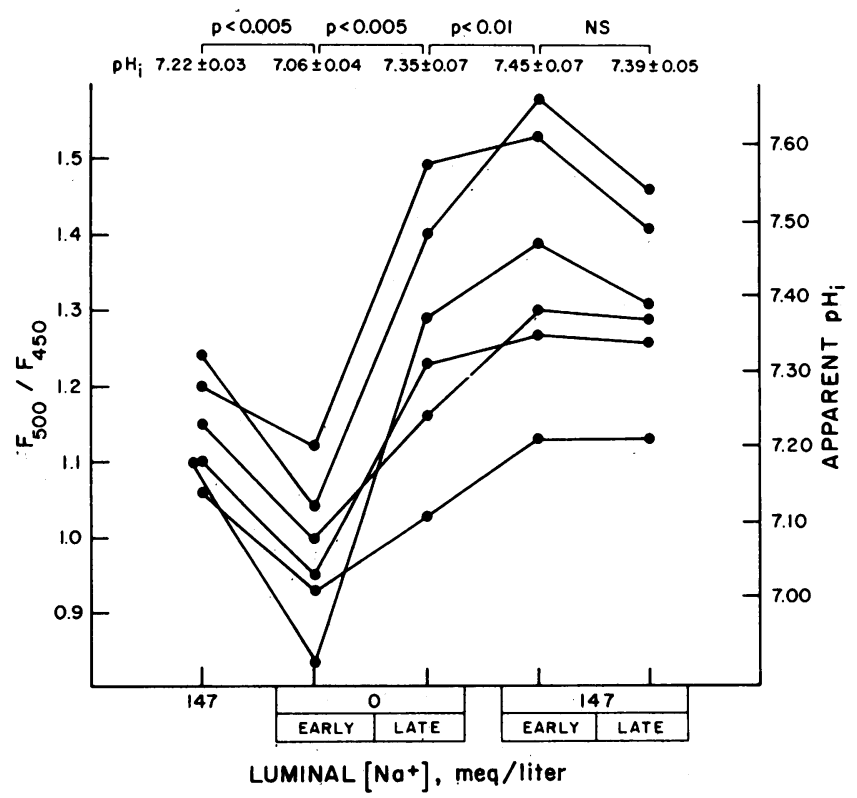

Figure 5. Effect of luminal sodium removal on cell $\mathrm{pH}$ in the presence of luminal organic solutes. Protocol as in the legend of Fig. 4. After a luminal fluid change, an early value was recorded which represented the peak or trough of the transient, and then a late steady-state value was recorded. Ordinate shows fluorescence excitation ratio on left and calculated cell $\mathrm{pH}$ on right.
$\mathrm{Na}\left(\mathrm{HCO}_{3}\right)_{n>1}$ symporter and other proton transporters in a direction which will decrease the magnitude of the cell acidification.

In order to examine more directly the possible existence of an apical membrane $\mathrm{Na} / \mathrm{H}$ antiporter, the previous studies were repeated in the absence of luminal organic solutes. Lumens were perfused with perfusate $25 \mathrm{HCO}_{3}-0 \mathrm{ORG}$ (Table I) in the initial control and recovery periods, and perfusate $0 \mathrm{Na}-25 \mathrm{HCO}_{3}-0 \mathrm{ORG}$ (Table I) in the experimental period. Peritubular capillaries were perfused with perfusate $25 \mathrm{HCO}_{3}$ throughout. In this setting, luminal sodium removal has a far lesser effect on cell potential difference (24).

A typical study is shown in Fig. 6. Once again removal of luminal sodium caused a transient cell acidification followed by alkalinization. Readdition of luminal sodium then alkalinized the cell. Fig. 7 shows the results of similar studies in eight tubules. When sodium was suddenly removed from the luminal perfusate, cell pH transiently decreased from $7.25 \pm 0.03$ in the control period to $7.21 \pm 0.02(P<0.005)$, and then rose at an initial rate of $0.08 \pm 0.01 \mathrm{pH}$ units/min to $7.32 \pm 0.03(P<0.001$ vs. early reading of experimental period; $P<0.005$ vs. initial control period). When sodium was added back to the luminal fluid, cell pH increased from $7.32 \pm 0.03$ to $7.40 \pm 0.04(P<0.025$ vs. late experimental period) and then remained stable.

In these studies without luminal organic solutes, luminal sodium removal led to a transient cell acidification followed by alkalinization, and then by further alkalinization upon readdition of luminal sodium. The magnitude of the transient acidification was less in this protocol than had been observed in the presence of luminal organics $(P<0.001)$, consistent with the hypothesis that in the absence of luminal organic solutes, hyperpolarization and its contribution to cell acidification are small or not occurring. The transient acidification in response to sodium removal and alkalinization in response to sodium readdition, are consistent with an apical membrane $\mathrm{Na} / \mathrm{H}$ antiporter.

The late alkalinization and the small magnitude of the cell 


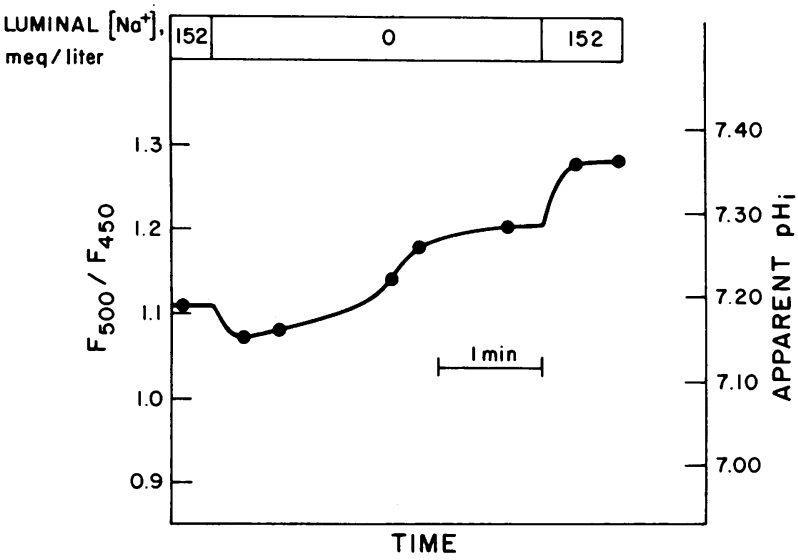

Figure 6. Effect of luminal sodium removal on cell pH in the absence of luminal organic solutes: typical study. Lumens were perfused with solutions containing $25 \mathrm{meq} /$ liter of bicarbonate, and either $152 \mathrm{meq} /$ liter of sodium or choline. Capillaries were perfused with a solution containing $25 \mathrm{meq} /$ liter bicarbonate throughout. (•) Fluorescent ratio measurements. Lines were drawn to connect the points, and to reflect transients observed with $500-\mathrm{nm}$ excitation at the time of a fluid change. Ordinate shows fluorescence excitation ratio on left and calculated cell $\mathrm{pH}$ on right.

acidification in response to luminal sodium substitution may have been due to secondary effects of altered cell sodium concentration and $\mathrm{pH}$ on the basolateral membrane $\mathrm{Na}\left(\mathrm{HCO}_{3}\right)_{n>1}$ symporter. In order to examine this possibility, and in an attempt to increase the response of cell $\mathrm{pH}$ to luminal sodium substitution, we examined the effect of luminal sodium removal in the absence of luminal organic solutes, and in the presence of peritubular SITS. Lumens were perfused with perfusate $25 \mathrm{HCO}_{3}-$ $0 O R G$ in the initial control and recovery periods, and perfusate $0 \mathrm{Na}-25 \mathrm{HCO}_{3}-0 \mathrm{ORG}$ in the experimental period. Peritubular capillaries were perfused with perfusate $5 \mathrm{HCO}_{3}$ with $0.5 \mathrm{mM}$ SITS added.

In the initial control period, cell pH was $7.26 \pm 0.07$ (Fig. 8). When luminal sodium was removed, cell $\mathrm{pH}$ decreased by 0.23

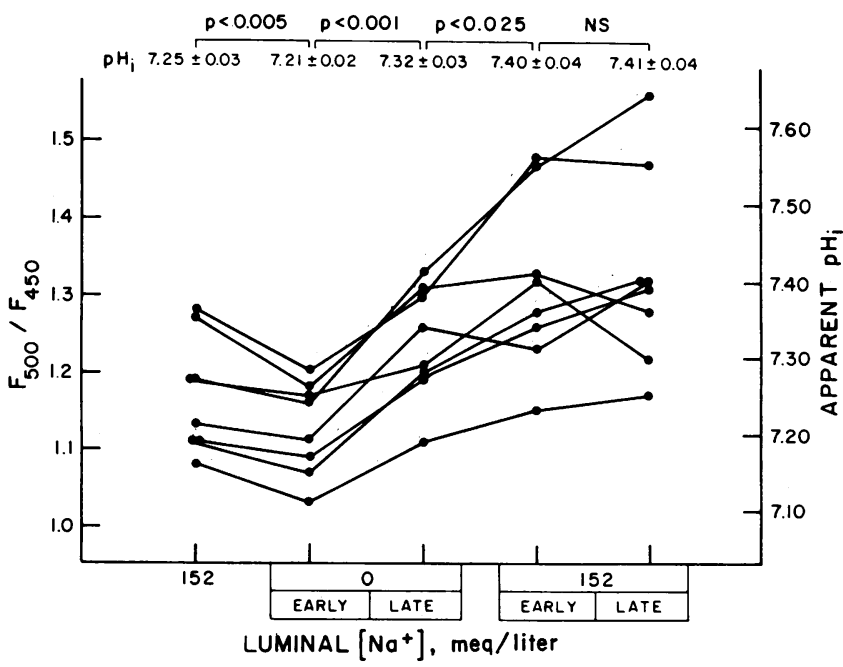

Figure 7. Effect of luminal sodium removal on cell $\mathrm{pH}$ in the absence of luminal organic solutes. Protocol as in the legend of Fig. 6. After a luminal fluid change, an early value was recorded which represented the peak or trough of the transient, and then a late steady-state value was recorded. Ordinate shows fluorescence excitation ratio on left and calculated cell $\mathrm{pH}$ on right.
pH units to $7.03 \pm 0.08(P<0.001)$. After the cell pH decreased, the zero sodium perfusate was continued for $\sim 1-2 \mathrm{~min}$. During this time period, cell pH was virtually constant (increased from $7.03 \pm 0.08$ to $7.05 \pm 0.07$, at the rate of $0.02 \pm 0.01 \mathrm{pH}$ units $/ \mathrm{min}$, NS). Return of luminal sodium then caused cell $\mathrm{pH}$ to increase by $0.27 \mathrm{pH}$ units to $7.32 \pm 0.07(P<0.001)$. Thus, inhibition of the basolateral membrane $\mathrm{Na}\left(\mathrm{HCO}_{3}\right)_{n>1}$ transporter markedly enhanced the cell acidification seen in response to luminal sodium removal $(P<0.001)$, and the cell alkalinization in response to sodium readdition $(P<0.001)$. It also inhibited the late alkalinization during luminal sodium removal $(P<0.005)$.

In order to prove that the changes in cell $\mathrm{pH}$ which occur in response to luminal sodium removal are due to the $\mathrm{Na} / \mathrm{H}$ antiporter, we examined the effect of amiloride. Amiloride has been demonstrated to inhibit the apical membrane $\mathrm{Na} / \mathrm{H}$ antiporter in rabbit renal cortical brush border membrane vesicles $(25,26)$. Because at least part of the inhibitory effect of amiloride involves competition with sodium, we chose to examine this question with lower luminal sodium concentrations. We examined the effect of $2 \mathrm{mM}$ amiloride on the response of cell $\mathrm{pH}$ to changing luminal sodium concentration from 75 to $0 \mathrm{meq} /$ liter, while the basolateral membrane bicarbonate transporter was inhibited with SITS. For these studies, lumens were perfused with perfusate $75 \mathrm{Na}-25 \mathrm{HCO}_{3}-0 \mathrm{ORGSO} \mathrm{PO}_{4}$ in the control and recovery periods, and with perfusate $0 \mathrm{Na}-25 \mathrm{HCO}_{3}$ $00 \mathrm{RGSO}_{4} \mathrm{PO}_{4}$ in the experimental period. Sulfate and phosphate were removed from these perfusates in order to improve solubility of amiloride and allow $2 \mathrm{mM}$ amiloride to go into solution.

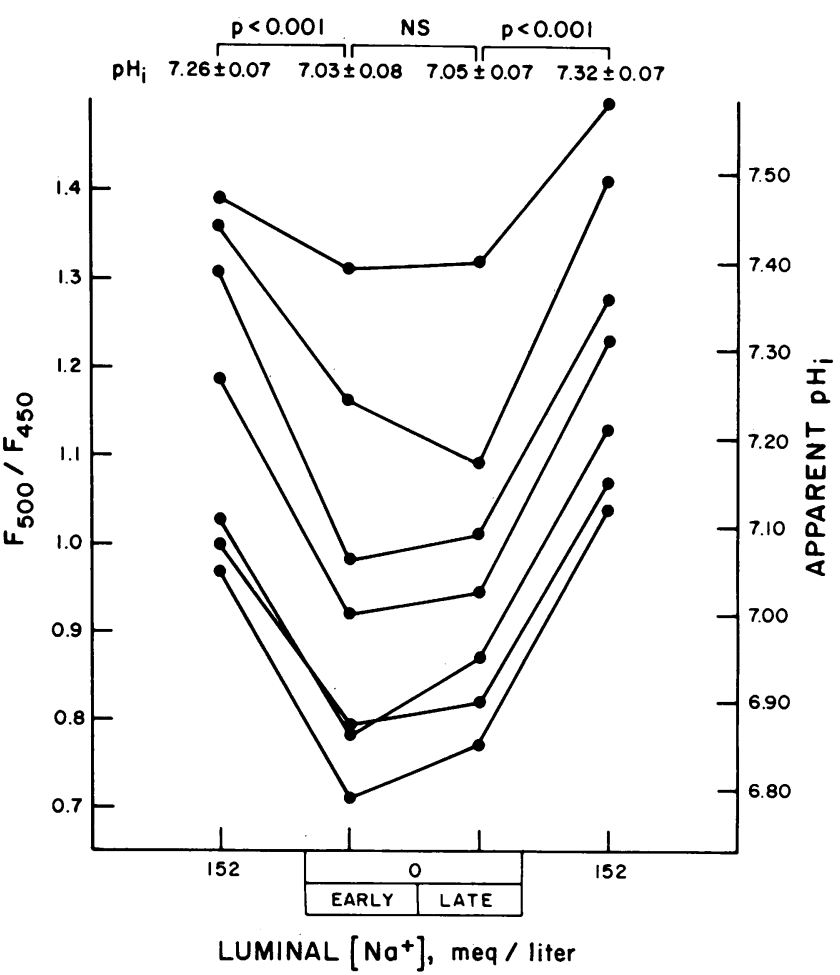

Figure 8. Effect of luminal sodium removal on cell pH in the absence of luminal organic solutes, with inhibition of the basolateral membrane bicarbonate transport mechanism. Peritubular capillaries were perfused with a solution containing $5 \mathrm{meq} / \mathrm{liter}$ bicarbonate and 0.5 mM SITS. Lumens were perfused with solutions containing $25 \mathrm{meq} /$ liter bicarbonate with either $152 \mathrm{meq} / \mathrm{liter}$ sodium or choline. Ordinate shows fluorescence excitation ratio on left and calculated cell pH on right. 
Peritubular capillaries were perfused with perfusate $5 \mathrm{HCO}_{3}$ with $0.5 \mathrm{mM}$ SITS added.

In the absence of luminal amiloride when luminal fluid contained $75 \mathrm{meq} / \mathrm{liter}$ sodium, cell pH was 6.92 \pm 0.07 . Removal of luminal sodium caused cell $\mathrm{pH}$ to decrease to $6.69 \pm 0.05$ ( $P$ $<0.005$ ); return of luminal sodium caused cell $\mathrm{pH}$ to return to $6.91 \pm 0.05(P<0.005)$. In the presence of $2 \mathrm{mM}$ amiloride (present in both luminal perfusates), cell pH was $6.85 \pm 0.03$ in the control period, decreased to $6.72 \pm 0.02$ when sodium was removed from the lumen $(P<0.005)$, and returned to $6.82 \pm 0.04$ when sodium was returned $(P<0.05)$. The cell $\mathrm{pH}$ response to sodium removal was greater in the absence of amiloride $(0.23 \pm 0.03 \mathrm{pH}$ units) than in the presence of amiloride $(0.11 \pm 0.03 \mathrm{pH}$ units; $P<0.02)$.

A more impressive effect of amiloride was seen when the rate at which cell $\mathrm{pH}$ changed in response to luminal sodium removal was examined. In the absence of luminal amiloride, luminal sodium removal caused the cell to acidify at an initial rate of $1.87 \pm 0.19 \mathrm{pH}$ units/min, while in the presence of amiloride, this acidification occurred at the rate of $0.35 \pm 0.05 \mathrm{pH}$ units/min. Thus, the response of cell $\mathrm{pH}$ to lowering luminal sodium from 75 to $0 \mathrm{meq} /$ liter was slowed by $81 \%$ by $2 \mathrm{mM}$ amiloride.

\section{Discussion}

Methods. In earlier studies we have demonstrated that changes in peritubular capillary perfusate composition did not affect luminal fluid composition (4). In the present set of studies, we utilized rapid retrograde perfusion, as described by Fromter and Gessner (21), to control the luminal fluid composition. This technique has the advantage of allowing rapid luminal fluid changes with the least number of tubular punctures. This technique provided excellent control of luminal fluid composition, and did not affect the response of cell $\mathrm{pH}$ to changes in peritubular pH (Fig. 2) or peritubular sodium concentration (data not shown), as compared to our previously measured responses at more physiologic luminal flow rates (4).

Cell $\mathrm{pH}$ values tended to be higher by $\sim 0.05$ to $0.15 \mathrm{pH}$ units in these studies with rapid retrograde perfusion than they were in our earlier studies with more physiologic perfusion rates (4). In addition, there was a tendency for slow cell alkalinization throughout the studies. When all studies were considered where tubules were perfused initially and at a later time with perfusate $25 \mathrm{HCO}_{3}$ in lumen and capillaries, cells were found to alkalinize at the rate of $0.02 \pm 0.01 \mathrm{pH}$ units $/ \mathrm{min}(n=40) .^{3}$ In addition, when tubules were perfused continuously with perfusate $25 \mathrm{HCO}_{3}$ (time controls), cell $\mathrm{pH}$ rose at a steady rate of $0.02 \pm 0.01 \mathrm{pH}$ units/min $(n=6)$. This may occur for two reasons. First, in our previous studies (4), the acetoxymethyl derivative of BCECF was perfused continuously throughout the experiment, while in these studies perfusion with the dye was stopped prior to measurements. Continuous perfusion leads to the continuous breakage of ester linkages which releases acid into the cell. While the magnitude of acid released was small $(8 \mathrm{peq} / \mathrm{min})^{4}$ compared with the rate of proximal tubular proton fluxes (200 peq/

3. This was calculated from data in Figs. 2, 3, 5, and 7, and from other data not presented in this manuscript, but using the same methods. 4. It is not known exactly how many millimeters of tubule this acid load was distributed over. In general, $>1 \mathrm{~mm}$ of tubule was loaded with dye, but the highest concentration of dye was in the loop the loading pipette had been in (where measurements were made). $\mathrm{mm} \cdot \mathrm{min}$ ), this may have affected cell pH slightly. Second, it is possible that increased luminal flow rates increase the rate of apical membrane transporters, and secondarily alkalinize the cell. Such an effect of flow rate has been previously postulated by us (27) and others (28).

Relative roles of luminal and peritubular $\mathrm{pH}$ as determinants of cell $\mathrm{pH}$. In the present studies, when luminal $\mathrm{pH}$ was decreased by $0.7 \mathrm{pH}$ units, cell pH decreased by $0.08 \mathrm{pH}$ units (Fig. 2). A similar change in the $\mathrm{pH}$ of the peritubular capillary fluid caused cell $\mathrm{pH}$ to decrease by $0.32 \mathrm{pH}$ units (Fig. 2). This latter result was similar to that reported by us at more physiologic luminal flow rates (4). These results imply that the rate of the basolateral membrane mechanism is more sensitive to changes in transmembrane $\mathrm{pH}$ gradient than are the rates of the apical mechanisms.

If the basolateral membrane transporter is sensitive to changes in cell composition, it then might be able to blunt cell $\mathrm{pH}$ changes, particularly in response to changes in apical membrane proton transport. One prediction of this thesis is that inhibition of the basolateral membrane transport mechanism will enhance the response of cell $\mathrm{pH}$ to changes in luminal $\mathrm{pH}$. We have previously shown that $>90 \%$ of proton transport (or its equivalent, bicarbonate) across the basolateral membrane is mediated by an electrogenic, $\mathrm{Na}\left(\mathrm{HCO}_{3}\right)_{n>1}$ transporter which is inhibited by SITS (4). Therefore we examined the effect of peritubular SITS on the response of cell $\mathrm{pH}$ to luminal $\mathrm{pH}$ changes. Peritubular SITS has previously been shown to alkalinize the cell (4), which by itself will inhibit the apical membrane $\mathrm{Na} / \mathrm{H}$ antiporter (29). To prevent this, we used a peritubular bicarbonate concentration of $5 \mathrm{meq} / \mathrm{liter}$. As predicted, addition of peritubular SITS enhanced the response of cell $\mathrm{pH}$ to a $0.7 \mathrm{pH}$ unit luminal acidification ( $\Delta \mathrm{pH}=0.19$ in the presence of SITS vs. $0.08-0.10$ in the absence of SITS):

Thus, the basolateral membrane $\mathrm{Na}\left(\mathrm{HCO}_{3}\right)_{n>1}$ transporter is an important determinant of cell $\mathrm{pH}$, and is able to respond to changes in cell composition. Changes in luminal fluid composition lead to changes in the rate of apical membrane transporters which secondarily alter cell composition (cell $\mathrm{pH}$ and [Na]). These changes in cell composition secondarily alter the rate of the basolateral membrane bicarbonate transport mechanism.

Luminal sodium substitution: effects on apical and basolateral membrane transporters. Luminal sodium removal was found to have a complex effect on cell $\mathrm{pH}$, causing an initial acidification followed by a late alkalinization. One component of the early acidification is cell hyperpolarization. Removing luminal sodium in the presence of luminal organic solutes (glucose and alanine) causes cell hyperpolarization due to cessation and reversal of the Na-coupled transporters (24). When luminal organic solutes were not present, the acidifying response to luminal sodium removal was smaller because cell hyperpolarization, if it occurred, was probably smaller (24).

The late alkalinization and small magnitude of the acidification (in the absence of luminal organic solutes) appears to be mainly due to slowing and possibly reversal of the basolateral membrane $\mathrm{Na}\left(\mathrm{HCO}_{3}\right)_{n>1}$ cotransporter. The major evidence in favor of this is that inhibition of the basolateral membrane transporter with SITS increased the magnitude of the early acidification and prevented the late alkalinization. A similar biphasic response to luminal sodium removal was seen by Boron and Boulpaep (6) in the salamander proximal tubule. These authors also proposed that the late alkalinization was due to a secondary 
effect of cell composition on the basolateral membrane transport mechanism.

In preliminary results from a mathematical model created to simulate the proximal tubule cell (30), the model predicted a biphasic response in cell $\mathrm{pH}$ to luminal sodium removal (similar to that observed in the present studies). By examining individual fluxes, we found that the early acidification was due to reversal of the $\mathrm{Na} / \mathrm{H}$ antiporter, and was associated with a decrease in cell [Na]. The change in cell $\mathrm{pH}$ and [Na] then caused the basolateral membrane bicarbonate transporter to slow. In the model, the late alkalinization was associated with a constant proton efflux by an apical membrane $\mathrm{H}^{+}$-ATPase and a slowing of effective proton entry (bicarbonate efflux) on the $\mathrm{Na}\left(\mathrm{HCO}_{3}\right)_{n>1}$ transporter. Inhibition of the basolateral membrane transporter, as would be expected to occur in the SITS experiments, prevented the biphasic time course.

The third component in this complex biphasic response is the apical membrane $\mathrm{Na} / \mathrm{H}$ antiporter. In the absence of luminal organic solutes and in the presence of peritubular SITS, removal of luminal sodium caused a large decrease in cell pH. Even if cell potential difference is affected by luminal sodium removal in the absence of luminal organic solutes, we have previously demonstrated that changes in cell potential do not affect cell $\mathrm{pH}$ when the basolateral membrane bicarbonate transporter is inhibited (4).

In order to confirm that this acidification was due to the $\mathrm{Na} / \mathrm{H}$ antiporter, we examined its sensitivity to amiloride. While studies in rabbit brush border membrane vesicles have found that the $\mathrm{Na} / \mathrm{H}$ antiporter is very sensitive to amiloride $(25,26)$, similar studies in rat brush border vesicles have found less sensitivity to amiloride $(31,32)$. Based on the data of Kinsella and Sacktor (31), and of Sabolic and Burckhardt (32) in rat brush border membrane vesicles, one would predict that $2 \mathrm{mM}$ amiloride in the presence of $75 \mathrm{meq} / \mathrm{liter} \mathrm{Na}$ would inhibit $\mathrm{Na} / \mathrm{H}$ exchange by $81 \%$ and $67 \%$, respectively. These predictions are relatively similar to our finding that the rate of $\mathrm{pH}$ change after luminal sodium removal was inhibited by $81 \%$ by $2 \mathrm{mM}$ amiloride.

A Na/H antiporter has been clearly demonstrated to be present in brush border membrane vesicle preparations (8-10). Studies examining the effect of sodium removal or inhibition of sodium transport on bicarbonate absorption have suggested that the $\mathrm{Na} / \mathrm{H}$ antiporter is present on the apical membrane (1217). In addition, proximal tubular bicarbonate absorption in the rat PCT is inhibited by luminal amiloride (33). Boron and Boulpaep (11) have directly demonstrated an apical membrane electroneutral $\mathrm{Na} / \mathrm{H}$ antiporter in Ambystoma proximal tubule in studies examining the effect of luminal sodium on recovery of cell $\mathrm{pH}$ from an intracellular acid load. In preliminary studies, Chaillet and Boron (34) have found similar results in the rabbit proximal straight tubule. Using microelectrodes, Sasaki et al. (35) have also found a $\mathrm{Na} / \mathrm{H}$ antiporter on the apical membrane of the rabbit proximal straight tubule. In the present study we have directly demonstrated apical membrane $\mathrm{Na} / \mathrm{H}$ exchange in the rat PCT.

Cell model. The present and other studies suggest the following model for transcellular proton secretion in the rat proximal convoluted tubule. Protons are secreted from cell to lumen across the apical membrane by $\mathrm{a} \mathrm{Na} / \mathrm{H}$ antiporter, and possibly by $\mathrm{H} \mathrm{H}^{+}$-ATPase. This leads to formation of base equivalents in the cell which leave in the form of bicarbonate across the basolateral membrane transporter. Present evidence suggests that this transporter is electrogenic and transports two to three bicarbonate ions with one sodium ion out of the cell $(4,5)$. In the steady state, fluxes across the apical and basolateral membranes are equal, and cell $\mathrm{pH}$ is the value required to keep the fluxes equal.

Lowering peritubular $\mathrm{pH}$ from 7.3 to 6.6 increases the rate of bicarbonate efflux across the basolateral membrane. This leads to a marked decrease in cell $\mathrm{pH}$ which stimulates the rate of apical membrane proton secretion in three ways: $(a)$ directly affecting the driving force; $(b)$ allosterically regulating the $\mathrm{Na}$ / $\mathrm{H}$ antiporter (29); and (c) causing insertion of apical membrane containing proton pumps (36). This sensitivity of the apical membrane transporters to cell $\mathrm{pH}$ causes the change in cell $\mathrm{pH}$ to be only $46 \%$ of the change in peritubular $\mathrm{pH}$.

We have previously shown that lowering luminal $\mathrm{pH}$ from 7.3 to 6.6 causes the rate of proton transport to decrease by approximately two thirds (1). This effect is directly expressed at the apical membrane which leads to a fall in cell $\mathrm{pH}$ that secondarily causes the basolateral membrane transporter to slow. Because the basolateral membrane transporter is very sensitive to $\mathrm{pH}$, it will decrease its rate by two thirds in response to a very small change in cell $\mathrm{pH}$. Thus, in response to a change in luminal $\mathrm{pH}$, cell $\mathrm{pH}$ changes by only $12 \%$ of the imposed luminal $\mathrm{pH}$ change.

The present studies also raise the possibility that changes in cell sodium concentration may effect communication between the apical and basolateral membranes. The biphasic response to luminal sodium removal indicates that at least one of the cell's proton translocating mechanisms can respond to a component of cell composition other than cell $\mathrm{pH} .^{5}$ In this setting, the most likely determinant is cell sodium concentration. Indeed, in the model which we have developed (30), a basolateral membrane bicarbonate transport mechanism regulated by cell sodium concentration was required for the biphasic response of cell $\mathrm{pH}$ to luminal sodium removal.

Thus, stimulation of the apical membrane $\mathrm{Na} / \mathrm{H}$ antiporter would raise cell sodium concentration, which would secondarily stimulate basolateral membrane $\mathrm{NaHCO}_{3}$ efflux. Stimulation of basolateral membrane $\mathrm{NaHCO}_{3}$ efflux would lower cell sodium concentration which would stimulate apical membrane $\mathrm{Na} / \mathrm{H}$ exchange. Two mechanisms of communication between the membranes (cell $\mathrm{pH}$ and cell sodium concentration) would allow the membranes to respond to apical or peritubular pertubations at the same rate with a lesser effect on intracellular concentrations of any one component. Further studies are required to more directly examine the effect of intracellular $\mathrm{pH}$ and sodium concentration on basolateral membrane $\mathrm{Na} / \mathrm{HCO}_{3}$ cotransport.

\section{Acknowledgments}

The authors are grateful to Floyd C. Rector, Jr. for his continuing support and advice throughout the performance of these studies. The authors

5. If each of the processes that regulate the concentration of a substance, $x$, is a continuously differentiable function of only $[x]$, then $d[\mathrm{x}] / \mathrm{d} t$ will be continuously differentiable function of only $[x]$. In this setting, one will not see a biphasic response in $[x]$. A biphasic response means that $d[\mathrm{x}] / \mathrm{d} t$ must go from positive to negative or negative to positive. However, to do this $[x]$ will pass through a point where $d[x] / \mathrm{d} t=0$. At this point, $[x]$ will be at the steady-state concentration and not change further. If another substrate which regulates $d[x] / \mathrm{d} t$ is changing, then $[x]$ can continue to change at this point. Thus the biphasic response of cell $\mathrm{pH}$ after luminal sodium removal implies that there is a second determinant of these transport processes, most likely cell sodium concentration. 
also gratefully acknowledge the excellent secretarial assistance of Gracie Bernacki.

These studies were supported by grant AM-27045 from the National Institute of Arthritis, Diabetes, and Digestive and Kidney Diseases, and by generous grants from MSC Hampton/Huntington Funds and the Hedco Foundations. Dr. Alpern is the recipient of a Clinical Investigator Award (AM-01229) from the National Institute of Arthritis, Diabetes, and Digestive and Kidney Diseases.

\section{References}

1. Alpern, R. J., M. G. Cogan, and F. C. Rector, Jr. 1982. Effect of luminal bicarbonate concentration on proximal acidification in the rat. Am. J. Physiol. 243:F53-F59.

2. Alpern, R. J., M. G. Cogan, and F. C. Rector, Jr. 1983. Effects of extracellular fluid volume and plasma bicarbonate concentration on proximal acidification in the rat. J. Clin. Invest. 71:736-746.

3. Alpern, R. J. 1984. Bicarbonate-water interactions in the rat proximal convoluted tubule: an effect of volume flux on active proton secretion. J. Gen. Physiol. 84:753-770.

4. Alpern, R. J. 1985. Mechanism of basolateral membrane $\mathrm{H}^{+} / \mathrm{OH}^{-} /$ $\mathrm{HCO}_{3}^{-}$transport in the rat proximal convoluted tubule: a sodium-coupled electrogenic process. J. Gen. Physiol. 86:613-636.

5. Yoshitomi, K., B.-C. Burckhardt, and E. Fromter. 1985. Rheogenic sodium-bicarbonate cotransport in the peritubular cell membrane of rat renal proximal tubule. Pflügers Arch. Eur. J. Physiol. 405:360-366.

6. Boron, W. F., and E. L. Boulpaep. 1983. Intracellular pH regulation in the renal proximal tubule of the salamander: basolateral $\mathrm{HCO}_{3}$ transport. J. Gen. Physiol. 81:53-94.

7. Biagi, B. A. 1985. The effects of the anion transport inhibitor, SITS, on the proximal straight tubule of the rabbit perfused in vitro. $J$. Membr. Biol. 81:25-32.

8. Kinsella, J. L., and P. S. Aronson. 1980. Properties of the $\mathrm{Na}^{+}$$\mathrm{H}^{+}$exchanger in renal microvillus membrane vesicles. Am. J. Physiol. 238:F461-F469.

9. Murer, H., U. Hopfer, and R. Kinne. 1976. Sodium/proton antiport in brush border membrane vesicles isolated from rat small intestine and kidney. Biochem. J. 154:597-604.

10. Warnock, D. G., W. W. Reenstra, and V. J. Yee. 1982. $\mathrm{Na}^{+} / \mathrm{H}^{+}$ antiporter of brush border vesicles: studies with acridine orange uptake. Am. J. Physiol. 242:F733-F739.

11. Boron, W. F., and E. L. Boulpaep. 1983. Intracellular pH regulation in the renal proximal tubule of the salamander: $\mathrm{Na}-\mathrm{H}$ exchange. J. Gen. Physiol. 81:29-52.

12. Burg, M., and N. Green. 1977. Bicarbonate transport by isolated perfused proximal convoluted tubules. Am. J. Physiol. 233:F307-F314.

13. McKinney, T. D., and M. B. Burg. 1977. Bicarbonate and fluid absorption by renal proximal straight tubules. Kidney Int. 12:1-8.

14. Chan, Y. L., and G. Giebisch. 1981. Relationship between sodium and bicarbonate transport in the rat proximal convoluted tubule. $\mathrm{Am}$. J. Physiol. 240:F222-F230.

15. Chantrelle, B., M. G. Cogan, and F. C. Rector, Jr. 1982. Evidence for coupled sodium/hydrogen exchange in the rat superficial proximal convoluted tubule. Pflügers Arch. Eur. J. Physiol. 395:186-189.

16. Schwartz, G. J. 1981. $\mathrm{Na}^{+}$-dependent $\mathrm{H}^{+}$efflux from proximal tubule: evidence for reversible $\mathrm{Na}^{+}-\mathrm{H}^{+}$exchange. Am. J. Physiol. 241: F380-F385.

17. Sasaki, S., C. A. Berry, and F. C. Rector, Jr. 1983. Effect of potassium concentration on bicarbonate reabsorption in the rabbit proximal convoluted tubule. Am. J. Physiol. 244:F122-F128.
18. Moolenaar, W. H., R. Y. Tsien, P. T. van der Saag, and S. W. de Laat. 1983. $\mathrm{Na}^{+} / \mathrm{H}^{+}$exchange and cytoplasmic $\mathrm{pH}$ in the action of growth factors in human fibroblasts. Nature (Lond.). 304:645-648.

19. Rink, T. J., R. Y. Tsien, and T. Pozzan. 1982. Cytoplasmic pH and free $\mathrm{Mg}^{2+}$ in lymphocytes. J. Cell Biol. 95:189-196.

20. Thomas, J. A., R. N. Buchsbaum, A. Zimniak, and E. Racker. 1979. Intracellular pH measurements in Ehrlich ascites tumor cells utilizing spectroscopic probes generated in situ. Biochemistry. 18:2210 2218.

21. Fromter, E., and K. Gessner. 1974. Active transport potentials, membrane diffusion potentials, and streaming potentials across rat kidney proximal tubule. Pflügers Arch. Eur. J. Physiol. 351:85-98.

22. Burckhardt, B.-C., A. C. Cassola, and E. Fromter. 1984. Electrophysiological analysis of bicarbonate permeation across the peritubular cell membrane of rat kidney proximal tubule. II. Exclusion of $\mathrm{HCO}_{3}^{-}$ effects on other ion permeabilities and of coupled electroneutral $\mathrm{HCO}_{3}^{-}$transport. Pflügers Arch. Eur. J. Physiol. 401:43-51.

23. Yoshitomi, K., and E. Fromter. 1984. Cell pH of rat renal proximal tubule in vivo and the conductive nature of peritubular $\mathrm{HCO}_{3}^{-}$ (OH $\left.{ }^{-}\right)$exit. Pflügers Arch. Eur. J. Physiol. 402:300-305.

24. Fromter, E. 1979. Solute transport across epithelia: what can we learn from micropuncture studies on kidney tubules? J. Physiol. (Lond.). 288:1-31.

25. Kinsella, J. L., and P. S. Aronson. 1981. Amiloride inhibition of the $\mathrm{Na}^{+}-\mathrm{H}^{+}$exchanger in renal microvillus membrane vesicles. $\mathrm{Am}$. J. Physiol. 241:F374-F379.

26. Ives, H. E., V. J. Yee, and D. G. Warnock. 1983. Mixed-type inhibition of the renal $\mathrm{Na}^{+} / \mathrm{H}^{+}$antiporter by $\mathrm{Li}^{+}$and amiloride: evidence for a modifier site. J. Biol. Chem. 258:9710-9716.

27. Alpern, R. J., M. G. Cogan, and F. C. Rector, Jr. 1983. Flow dependence of proximal tubular bicarbonate absorption. Am. J. Physiol. 245:F478-F484.

28. Harris, R. C., J. L. Seifter, and B. M. Brenner. 1984. Adaptation of $\mathrm{Na}^{+}-\mathrm{H}^{+}$exchange in renal microvillus membrane vesicles: role of dietary protein and uninephrectomy. J. Clin. Invest. 74:1979-1987.

29. Aronson, P. S., J. Nee, and M. A. Suhm. 1982. Modifier role of internal $\mathrm{H}^{+}$with the $\mathrm{Na}^{+}-\mathrm{H}^{+}$exchanger in renal microvillus membrane vesicles. Nature (Lond.). 299:161-163.

30. Verkman, A. S., and R. J. Alpern. 1986. Kinetic transport model for cellular regulation of $\mathrm{pH}$ and solute concentration in the renal proximal tubule. Biophys. J. 49:159a. (Abstr.)

31. Kinsella, J. L., and B. Sacktor. 1985. Thyroid hormones increase $\mathrm{Na}^{+}-\mathrm{H}^{+}$exchange activity in renal brush border membranes. Proc. Natl. Acad. Sci. USA. 82:3606-3610.

32. Sabolic, I., and G. Burckhardt. 1984. Effect of the preparation method on $\mathrm{Na}^{+}-\mathrm{H}^{+}$exchange and ion permeabilities in rat renal brushborder membranes. Biochim. Biophys. Acta. 772:140-148.

33. Howlin, K. J., R. J. Alpern, and F. C. Rector, Jr. 1985. Amiloride inhibition of proximal tubular acidification. Am. J. Physiol. 248:F773F778.

34. Chaillet, R., and W. F. Boron. 1984. Intracellular pH regulation in rabbit proximal tubules studied with a pH-sensitive dye (Abstr.). Kidney Int. 25:273.

35. Sasaki, S., Y. lino, T. Shiigai, and J. Takeuchi. 1984. Intracellular pH of isolated perfused rabbit proximal tubule: effects of luminal $\mathrm{Na}$ and $\mathrm{Cl}$ (Abstr.). Kidney Int. 25:282.

36. Schwartz, G. J., and Q. Al-Awqati. 1985. Carbon dioxide causes exocytosis of vesicles containing $\mathrm{H}^{+}$pumps in isolated perfused proximal and collecting tubules. J. Clin. Invest. 75:1638-1644. 